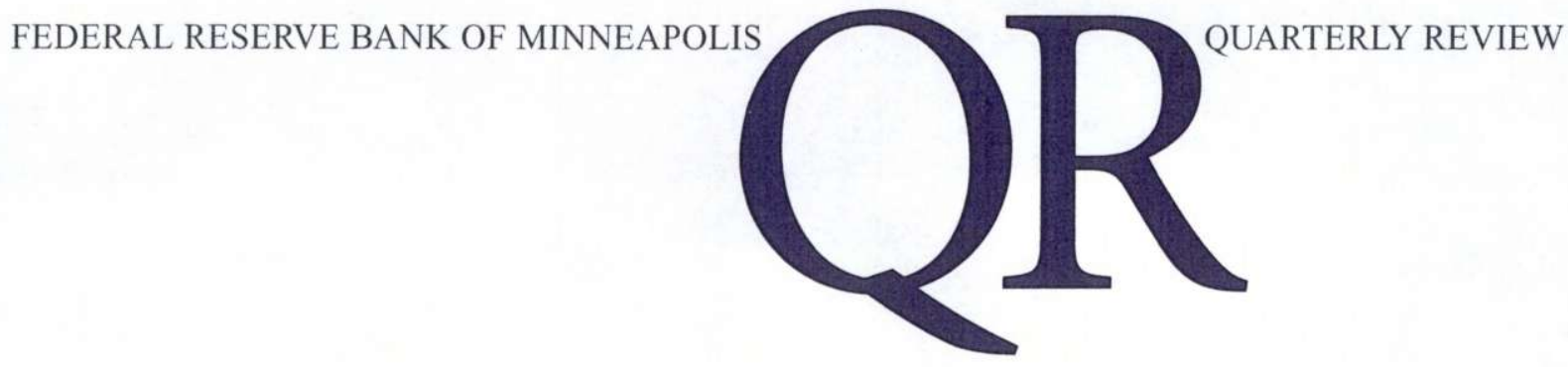

November 2007

\title{
On the Needed Quantity of Government Debt
}

Kathryn Birkeland Edward C. Prescott

Modeling Great Depressions: The Depression in Finland in the $1990 \mathrm{~s}$

Juan Carlos Conesa Timothy J. Kehoe Kim J. Ruhl 
FEDERAL RESERVE BANK OF MINNEAPOLIS

\section{Quarterly Review Vol.31, No.1}

\section{ISSN 0271-5287}

This publication primarily presents economic research aimed at improving policymaking by the Federal Reserve System and other governmental authorities.

Any views expressed herein are those of the authors and not necessarily those of the Federal Reserve Bank of Minneapolis or the Federal Reserve System.

EDITOR: Arthur J. Rolnick

ASSOCIATE EDITORS: Patrick J. Kehoe, Warren E. Weber

ARTICLE EDITOR: Joan M. Gieseke

PRODUCTION EDITOR: Joan M. Gieseke

DESIGNER: Phil Swenson

TYPESETTING: Mary E. Anomalay

CIRCULATION ASSISTANTS: Mary E. Anomalay, Barbara Drucker
The Quarterly Review is published by the Research Department of the Federal Reserve Bank of Minneapolis. Subscriptions are available free of charge. This has become an occasional publication, which is published once or twice a year. The publication, however, continues to be known as the Quarterly Review for citation purposes.

Quarterly Review articles that are reprints or revisions of papers published elsewhere may not be reprinted without the written permission of the original publisher. All other Quarterly Review articles may be reprinted without charge. If you reprint an article, please fully credit the source-the Minneapolis Federal Reserve Bank as well as the Quarterly Review-and include with the reprint a version of the standard Federal Reserve disclaimer (italicized left). Also, please send one copy of any publication that includes a reprint to the Minneapolis Fed Research Department.

Electronic files of Quarterly Review articles are available through the Minneapolis Fed's home page on the World Wide Web: http://www.minneapolisfed.org.

Comments and questions about the Quarterly Review may be sent to:

Quarterly Review

Research Department

Federal Reserve Bank of Minneapolis

P. O. Box 291

Minneapolis, MN 55480-0291

(Phone 612-204-6455/Fax 612-204-5515)

Subscription requests may be sent to the circulation assistant at mea@res.mpls.frb.fed.us. 


\section{On the Needed Quantity of Government Debt}

Kathryn Birkeland

Assistant Professor of Economics

University of Wisconsin-La Crosse

\author{
Edward C. Prescott \\ Senior Monetary Adviser \\ Research Department \\ Federal Reserve Bank of Minneapolis \\ and W. P. Carey Chair of Economics \\ Arizona State University
}

We need to change our way of thinking regarding government debt. First, the government debt that a country owes to its citizens is not debt in the usual sense of the word. This form of government debt is a mechanism that facilitates intergenerational borrowing and lending, and is an integral part of a welfare-improving savingfor-retirement system.

Second, because of changing demographics, the quantity of government debt needed in a saving-forretirement system is becoming large. The number of retired workers is growing because people are living longer and population growth has slowed in most of the advanced industrial countries. With these demographics, large government debt is a feature of the retirement financing system that maximizes the lifetime welfare of all, including our grandchildren - namely, the savingfor-retirement system. The alternative tax-and-transfer system, in which the government taxes workers' labor income or consumption (or both) to finance the consumption of retirees, has little or no government debt. However, the welfare for all, including our grandchildren, is much lower in the tax-and-transfer system.

Unlike the pure consumption loan model of Samuelson (1958), taxing the income of people when young and making lump-sum transfers to them when old is not equivalent to there being large quantities of explicit gov- ernment debt, which people buy during their working life and sell during their retirement life. Because people value their nonmarket time, taxing labor income or consumption (or both) lowers labor supply. The welfare of a saving-for-retirement system is much higher than the welfare of a tax-and-transfer system.

We begin with the Samuelson (1958) pure consumption loan model and show that a pay-as-you-go retirement system and a savings system are equivalent. This follows from Ricardian equivalence, since the tax is lump-sum and there are no redistributions. ${ }^{1}$ In this world, people receive a large endowment of the consumption good when young and a small endowment when old. They prefer smooth consumption over their lifetimes to consumption concentrated when young. Under the pay-as-you-go system, there is no government debt, whereas under the savings system, there is a large amount of government debt. We show that Ricardian equivalence holds and that someone born into either system enjoys the same level of welfare.

\footnotetext{
${ }^{1}$ An interesting but minor issue is associated with starting the savings system. This issue is addressed in Prescott and Ríos-Rull (2005), who develop an equilibrium concept for these environments with the property that the generation that sets up the system cannot do better than future generations in the same situation. If the initial generation did better, then all would choose to be the initial generation.
} 
We then modify the economy in an important way. Rather than having the endowment when young be the consumption good, the endowment is productive time. This time can be used in the market to produce the consumption good or can be used for valued nonmarket activities. We label nonmarket activities as leisure because this is a conventional practice in macroeconomics even though some nonmarket activities are nonmarket work. As has been established, the time allocation decision between market and nonmarket activities responds to incentives. Consequently, a deadweight loss is associated with taxing labor income of young people to finance lump-sum transfers to the old.

Some naively think that government debt is a burden on the young. This is not the case, since the welfare of the young and government debt are both large in the efficient saving-for-retirement system. Indeed, in the inferior tax-and-transfer system, government debt is zero. We go on to show that switching from a pay-asyou-go system to a savings system benefits everyone and incurs no costs. All that needs to be done to make the switch is to stop taxing labor income. During the transition period, transfers to the old would be financed by a large deficit and the stock of government debt would rise to its needed level.

The economies discussed so far have no reproducible productive assets; that is, there is no capital. In fact, large quantities of reproducible productive assets are held by households, on the order of 3.5 times annual gross national income (GNI). We introduce production using both capital and labor, where labor is time allocated to market production. We calibrate this model economy to the behavior of the advanced industrial countries including Australia, France, Japan, and the United States. This means that the model economies mimic the behavior of these actual economies on key aggregate dimensions given their policies.

We find that with a pure saving-for-retirement system, the ratio of government debt to annual GNI can be as high as 5 under plausible demographic assumptions. For the tax-and-transfer retirement system, the government owns the productive assets and there is no government debt.

Currently, implicit government liabilities are large. In the United States, the Medicare and Social Security implicit liabilities are many times GNI. The Congressional Budget Office estimates these liabilities to be about four times GNI. Legally, these implicit liabilities are not government debt. They are called responsibilities by the U.S. Treasury and mandated expenditures by the Congressional Budget Office.

We emphasize that financing retirement is not a problem of insurance. Getting older each year is a predictable event. In the case of the United States, the survivor and disability insurance programs and the welfare system are insurance, not retirement, programs. Financing retirement and providing insurance are fundamentally different activities and are best kept separated. In the case of annuities, of course, there is insurance within a cohort against living too long, since annuities are insurance against outliving savings. Annuities are provided by the private sector, as are many other forms of insurance. Therefore, we abstract from uncertain lifetimes, which eliminates the need for annuities. All our conclusions hold with uncertain lifetimes provided there are annuities.

\section{Three Examples}

In this section, we use a few examples to compare the consequences of tax-and-transfer systems and savingfor-retirement systems where the saving is in the form of government debt. First, we show that for a two-periodlived, pure consumption loan model, both the tax-andtransfer system and the saving-for-retirement system are preferable to autarky. Both systems maximize welfare but have starkly different levels of government debt.

Second, we consider a three-period-lived consumption loan model. In this model world, under the tax-andtransfer system, there is no government debt, yet people are born with net liabilities to the government because the present value of taxes exceeds the present value of transfers. With the saving-for-retirement system, which has large government debt, people are born with no liability to the government.

In the third example, we include valued nonmarket time in the two-period-lived overlapping generations model. Here, a tax on labor income in the tax-andtransfer system distorts the time allocation decision between market and nonmarket activities. As a result, the saving-for-retirement system with no labor income tax and large government debt is welfare improving. The lifetime welfare of a person being born into the saving-for-retirement system is 21 percent higher than in the tax-and-transfer system. The last example, in the subsection entitled "The Model with Capital Accumulation," adds capital accumulation to the model with valued nonmarket time. This example shows that the 
existence of capital accumulation serves to reduce the amount of government debt needed to achieve a steadystate allocation in a saving-for-retirement system.

\section{The Pure Consumption Loan Model}

People are endowed with 11 units of the consumption good when young and 1 unit when old. An equal number of people are born every period. A person born in period $t$ has preferences ordered by

$$
\log c_{1, t}+\log c_{2, t+1},
$$

where $c_{1}$ is consumption when young and $c_{2}$ is consumption when old. The second subscript indicates when the consumption occurs.

The period $t$ society resource constraint is

$$
c_{1, t}+c_{2, t} \leq 12 \text {. }
$$

All variables are per person; therefore, $c_{1, t}$ is consumption per young person at date $t$.

With no government, $c_{1, t}=11$ and $c_{2, t}=1$ for all $t$. A feasible allocation that is much better for all is $c_{1, t}=6$ and $c_{2, t}=6$ for all $t$. This can be supported as a competitive equilibrium with either of two very different government policies. The first has a government debt to output ratio of 5 . The young buy this debt from the old and sell it when they are old. Given the nature of preferences, the equilibrium interest rate is zero, and so government interest rate payments are zero and there is no deficit. If the endowment grew 50 percent per period, ${ }^{2}$ the interest would be positive and there would be the need for a deficit equal to one-quarter of total output. The deficit pays for the interest on the government debt. Currently, the ratio of explicit U.S. government debt to annual GDP is 0.3.

The second system taxes the endowment at rate $\tau=5 / 11$ and transfers the proceeds in equal shares to the old. The equilibrium allocation is the same as in the savings system with government debt. This allocation maximizes utility per generation. Therefore, both systems maximize welfare in this sense but have starkly different amounts of government debt.

\section{A Three-Period Consumption Loan Model}

We define the debt facing a person entering the workforce as the present value of taxes used to finance transfers minus the present value of transfers that the individual will receive. For this example, with the tax- and-transfer system, new entrants to the workforce have debt, whereas in the saving-for-retirement system, new entrants are debt free. This fact may seem surprising given that there is no government debt in the tax-andtransfer system, but there is a large quantity of government debt in the saving-for-retirement system. But the tax-and-transfer system, not the saving system, imposes a debt burden on future generations for the following example.

The individual's utility function is

$$
\log c_{1, t}+\frac{1}{(1+\rho)} \log c_{2, t+1}+\frac{1}{(1+\rho)^{2}} \log c_{3, t+2},
$$

where $c_{1}$ is consumption when young, $c_{2}$ is consumption when middle-aged, $c_{3}$ is consumption when old, and the discount rate $\rho$ is positive. The young and the middle-aged are endowed with 15 units of the consumption good. The old receive no endowment.

The first government policy is to tax the young and middle-aged to provide for the old. This policy has no government debt. The young and middle-aged will be taxed at a rate of one-third of their endowment. The government transfers the revenue lump-sum to the old. The equilibrium for this policy is $c_{1}=c_{2}=c_{3}=10$. The interest rate is $i=\rho$, and there is no government debt.

Under this tax-and-transfer system, each cohort has promises of transfers from the government when old. Each cohort must also pay taxes when young and when middle-aged. The present value of the taxes and transfers are specified in Table 1. Given that the interest rate is positive for this model economy, the present value of taxes exceeds the present value of benefits. This means that the young are born with debt even though there is no government debt for this policy. The present value of transfers less the present value of taxes is the sum of the entries in the table. The important point, given that the interest rate is strictly positive, is that the sum is negative, which means that people are born with a liability to the government.

The equilibrium for the saving-for-retirement system has the same consumption allocation and interest rate. Government debt held by the old (before receiving interest) is $10 /(1+i)$. The pre-interest government debt held by middle-aged people is 5 . Total government debt is

\footnotetext{
${ }^{2}$ Given that a period corresponds to 20 years, this growth rate is in line with the U.S. historical experience over the last 140 years (see McGrattan and Prescott 2003).
} 
Table 1

Present Value of Taxes and Transfers in the Tax-and-Transfer System

\begin{tabular}{lc}
\hline When Cohort Is & Present Value of Tax or Transfers \\
\hline Old & $10 /(1+i)^{2}$ \\
Middle-aged & $-5 /(1+i)$ \\
Young & -5
\end{tabular}

therefore $10 /(1+i)+5$. Given that there are no taxes or transfers, people enter the labor force with no liability to the government.

\section{Introducing Valued Nonmarket Time}

When Samuelson wrote his classic paper in 1958, the Lucas and Rapping (1969) paper introducing labor supply into macroeconomics had not yet been written. We now introduce labor supply into the Samuelson pure consumption loan model as follows. Rather than individuals being endowed with stocks of the consumption good, they are endowed with time, which they then allocate between market production and nonmarket activities:

$$
\log c_{1, t}+\log c_{2, t+1}-v_{1} l_{1, t}-v_{2} l_{2, t+1},
$$

where $v_{1}$ and $v_{2}$ are the disutility of labor supplied to the market parameters. Behind this utility is the Rogerson (1988) and Hansen (1985) labor indivisibility in the lifecycle framework (see Prescott, Rogerson, and Wallenius 2007 for endogenizing the indivisibility in a life-cycle setting). The values of the labor disutility parameters are $v_{1}=0.1$ and $v_{2}=1$. There is great disutility of working when old, which is why people retire in this economy.

The technology is such that one unit of time produces one unit of the consumption good, which implies that the equilibrium wages are $w_{t}=w=1$ for all $t$. In this section we will consider only those policies for which consumption when young equals consumption when old. Given these preferences, the implication is that the equilibrium interest rate must be zero. $t$ is

The budget constraint of a household born at date

$$
c_{1, t}+c_{2, t+1}=(1-\tau) w l_{1, t}+(1-\tau) w l_{2, t+1}+b,
$$

where $\tau$ is the tax rate on labor income, $w$ is the wage rate, and $b$ is the retirement benefits paid by the government. The government's budget constraints are

$$
b=\tau l_{t} w .
$$

If there are no transfers and no government debt, the equilibrium values of consumption and labor supply are

$$
c_{1}=10 ; \quad c_{2}=1 ; \quad l_{1}=10 ; \quad l_{2}=1 .
$$

This allocation can be improved upon. The following two systems are better for all.

\section{The Tax-and-Transfer System}

If transfers and taxes are such that consumptions of young and old are equal, the values of the policy parameters must be $\tau=0.5$ and $b=5$. The equilibrium values of the variables are $l_{1}=10$ and $l_{2}=0$, and $c_{1}=c_{2}=5$. This system has no government debt. It is better than no government, but it can be improved upon.

\section{The Government Debt System}

Government debt is selected so that the consumptions of the young and the old are equated. The equilibrium allocation is $l_{1}=20$ and $c_{1}=c_{2}=10$. Government debt is 10 and the interest rate is zero. The government debt to output ratio is 0.50 .

The tax-and-transfer system has lower consumption but more nonmarket time, which is valued by the household. The question remains: which system is better-and by how much? To answer this question, we determine by what percentage the two consumptions must be increased to compensate individuals for being born into a world with a tax-and-transfer system rather than a saving-for-retirement system. The percentage by which consumptions in the tax-and-transfer system must be increased for individuals to be indifferent between being born into that world or one with the savings system is 21 percent. Thus, the deadweight loss of a tax-and-transfer system to finance retirement versus a saving-for-retirement system is 21 percent in lifetime consumption equivalents.

This establishes that the government debt is not a burden per se on the young, because a young person would prefer to be born into a world with high government debt rather than one with no government debt. 


\section{The Model with Capital Accumulation}

The economies considered so far have no reproducible productive assets, namely, capital. Saving in the form of reproducible productive assets reduces the amount of government debt needed to support the steady-state allocation that maximizes the utility of people. ${ }^{3}$ We show this result in this section.

We modify the economy to have durable capital goods that enhance production possibilities. The production function is Cobb-Douglas with

$$
C_{t}+X_{t} \leq A K_{t}^{1 / 3} L_{t}^{2 / 3}
$$

The capital letters denote aggregate variables, with $C$ denoting consumption, $X$ denoting investment, $K$ denoting both capital services and capital stock (one unit of capital stock produces one unit of capital services), and $L$ denoting labor services. The choice of this Cobb-Douglas production function was dictated by the constancy of capital income share near $1 / 3$ over time and across countries. The capital depreciation rate is 100 percent, so

$$
K_{t+1}=X_{t} .
$$

Given that a period is 25 years, this depreciation rate is reasonable.

The capital-output ratio, $1 / 3$, is large in this economy. Given that a period is 25 years, the annualized capital income ratio is 25 times larger, or 8.33, which is almost twice the ratio for economies throughout the world. In the next two sections, we use a calibrated model to draw quantitative inferences as to the welfare consequences of different policies, where the capital-output ratio is in line with the real world. But this example suffices to make the point that less government debt is needed in the pure savings system if there is capital accumulation. We make the convenient normalization $A=(2 / 3)^{-2 / 3}$ and assume $v_{1}=1 / 3$. The disutility of working when old, $v_{2}$, is large enough that the old do not work, so an equilibrium relation is $l_{2}=0$.

The equilibrium allocation is $c_{1}=c_{2}=X=K=1$ and $l_{1}=3$. Aggregate output is 3 and capital income share is $1 / 3$. Thus, the amount of government debt is zero. This is because the labor income of the young is 2 , their consumption 1, and consequently their savings 1 . Since investment is 1 , the amount of government debt needed to support this allocation is zero. For this numerical example, savings in the form of capital eliminates the need for any government debt.

The examples in this section establish the need to use economic theory and measurement to examine the consequences of different debt, transfer, and tax policies to determine the amount of needed government debt relative to gross national income. We now use both theory and measurement to draw some inferences as to the needed amount of government debt.

\section{Model Economy Used for Policy Evaluation}

This section develops a model that we use to predict the consequences of two retirement policies under alternative demographic assumptions. In both cases, we find the balanced growth path with the property that the return on capital is 5 percent before taxes. This balanced growth path determines the size of transfers and government debt given the tax rates on labor and capital income. No equilibrium exists with the dynamic inefficiency of Diamond (1965) if borrowing and lending contracts are permitted by infinitely lived organizational entities. There will be an equilibrium for our policies because the policy-pegged interest rate exceeds the growth rate of the economy. Abel et al. (1989) empirically show that there is no dynamic inefficiency in the case of the United States. The interest rates and growth rates have been preset in a way that is consistent with the full equilibrium but which enables a simple balanced growth analysis. In the section entitled "Policy Evaluations Under Various Demographic Assumptions," we use the model to evaluate retirement policies under different demographic assumptions.

This model includes capital accumulation and extends the lifetime of each agent to $N$ years, with the first $N_{w}$ years being the working life and the last $N_{r}$ years being the retirement life. ${ }^{4}$ The inputs to production are capital services and labor services, as in the subsection entitled "The Model with Capital Accumulation." The assets that people hold are capital and government debt.

\section{The Model Economy}

\section{Fiscal Structure}

The fiscal policy parameters are $\left(\tau_{h}, \tau_{k},\left\{D_{t}, \psi_{t}\right\}_{t=0}^{\infty}\right)$, where $\tau_{h}$ is the tax rate on labor income, $\tau_{k}$ is the tax

\footnotetext{
${ }^{3}$ Introducing a nonreproducible productive asset, such as land, would not alter this conclusion. There would not be a need for government debt to achieve the allocation that is efficient with the savings system.

${ }^{4}$ In this model, we take the retirement age as given. See the work of Rogerson and Wallenius (2007) for endogenizing the retirement decision.
} 
rate on capital income net of depreciation, and $\left\{D_{t}, \psi_{t}\right\}$ is the paths of government debt $\left\{D_{t}\right\}$ and transfers to all people $\left\{\psi_{t}\right\}$.

The capital tax is paid by the owner of capital, the stand-in bank. The labor income tax is paid by the workers. The transfers are made lump-sum each period to all people in the economy in the same amount. Having a transfer to only retired agents would change the accounting in the economy, but not the equilibrium allocation. People save for retirement by holding assets at the stand-in bank, which owns the capital stock and any government debt.

\section{People}

A cohort is born every year with cohort size growing at rate $\eta$. We normalize the measure of the initial population to 100. The consumption of those younger than working age is implicitly included in their parents' consumption. People begin working at age 20 and are endowed with one unit of time each period of their working life, which is $N_{w}$ years, and then have a retirement life, which is $N_{r}$ years. Their lifetime is $N+20$ years, where $N=N_{w}+N_{r}$. In each year of their working life, people divide their time endowment between market work and leisure.

The lifetime utility of a person that enters the workforce in period $t=1$ is

$$
\begin{aligned}
& \sum_{t=1}^{N_{w}} \beta^{t-1}\left[(1-\alpha) \log c_{t}+\alpha \log \left(1-h_{t}\right)\right] \\
& +\sum_{t=N_{w}+1}^{N} \beta^{t-1}\left[(1-\alpha) \log c_{t}+\alpha \log (1)\right]
\end{aligned}
$$

People value consumption and leisure in each period. Since each person is endowed with one unit of time each period, the amount of leisure is simply $\left(1-h_{t}\right)$, where $h_{t}$ is the time allocated to the market. Retired people allocate no time to the market. The parameter $\alpha$ is the leisure share parameter. The parameter $\beta \leq 1$ is the rate at which people discount future utility. The first part of the utility function is the utility during the working lifetime, and the second part is the utility during retirement. Macroeconomic observations dictate this choice of utility function for the intertemporal leisure elasticity of substitution. These observations include business cycle facts, prosperities and depressions, and labor supply differences across the major advanced industrial countries. ${ }^{5}$
The lifetime budget constraint of an individual entering the workforce at the beginning of year 1 is

$$
\begin{aligned}
& \sum_{t=1}^{N} \frac{1}{(1+i)^{t-1}}\left(c_{t}-\psi_{t}\right) \\
& -\sum_{t=1}^{N_{W}} \frac{1}{(1+i)^{t-1}}\left(1-\tau_{h}\right) w_{t} h_{t}=0 .
\end{aligned}
$$

The present value of cash flows is zero.

Each year a worker chooses how much time to allocate to the market, how much to consume, and how much to save. Retired workers do not work and have no labor supply decision, just a consumption decision.

Define the agents that enter the workforce in period 1 as cohort 1 . The period budget constraints for the cohort 1 person are

$$
a_{t+1}=a_{t}\left(1+i_{t-1}\right)+\left(1-\tau_{h}\right) w_{t} h_{t}+\psi_{t}-c_{t},
$$

where $a_{t}$ is beginning of period $t$ assets. Initial assets of cohort 1 are $a_{1}=0$. The individual's allocation of assets between tangible capital and government debt is not determined. The sum, however, is determined, as is the aggregate holdings of these two assets. At the beginning of the period, interest is paid on the level of assets held at the end of last period. This interest rate, $i_{t-1}$, is determined in period $t-1$ and paid in period $t$. The tax rate on labor income is $\tau_{h}$, and the consumers' after-tax labor income in period $t$ is $\left(1-\tau_{h}\right) w_{t} h_{t}$.

\section{Stand-In Bank}

To handle the indeterminacy of individual portfolio composition, we introduce a stand-in bank. This bank has liabilities to individuals in the form of deposits or assets, $A_{t}$, and owns both the capital stock, $K_{t}$, and the government debt, $D_{t}$. Therefore, $A_{t}=K_{t}+D_{t}$. The bank rents the capital stock to the stand-in firm for use in production at the rate of $r_{t}$. After production, the firm returns the capital to the bank less depreciation. The bank chooses how much to invest in capital stock, pays interest to depositors, and pays any tax on net capital income.

The capital stock owned by the bank evolves according to

\footnotetext{
${ }^{5}$ See Prescott 2006.
} 


$$
K_{t+1}=(1-\delta) K_{t}+X_{t},
$$

where $X_{t}$ denotes investment and $0<\delta<1$ is the depreciation rate. The technology of the stand-in bank displays constant returns to scale so profits are zero, and we need not worry about ownership of the bank. Therefore, the interest rate paid on assets is exactly equal to the after-tax net income from renting the capital. This means that

$$
i_{t-1}=\left(1-\tau_{k}\right)\left(r_{t}-\delta\right)
$$

must be satisfied, where $r_{t}$ is the year $t$ rental price of capital and $\tau_{k}$ is the tax rate on net capital income.

\section{Stand-In Firm}

The firm rents capital services from the bank and labor services from the households for use in producing output that can be used for consumption or investment. The production function of the stand-in firm is

$$
Y_{t}=K_{t}^{\theta}\left(Z_{t} H_{t}\right)^{1-\theta}
$$

The parameter $Z_{t}$ grows at rate $\gamma$, and the parameter $\theta$ is the capital share parameter. The equilibrium wage rate is equal to the marginal product of labor, and the rental rate of capital is equal to the marginal product of capital. The production technology of the stand-in firm displays constant returns to scale; therefore, we need not worry about the ownership of the firm.

\section{Government}

The government in the model economy receives revenue from a tax on labor income and net capital income:

$$
\text { Revenue }_{t}=\tau_{k}\left(r_{t}-\delta\right) K_{t}+\tau_{h} w_{t} H_{t}
$$

The government spends this revenue on a lump-sum transfer to all individuals and interest payments on government debt. Let $\Psi_{t}=N \psi_{t}$ denote aggregate transfers. The law of motion for the amount of government debt is

$$
D_{t+1}=\Psi_{t}+i_{t-1} D_{t}-\text { Revenue }_{t} .
$$

Fiscal policy is such that the steady-state after-tax interest rate, $i$, is 4 percent. Within this model economy, we consider two policies for financing retirement. The first is a pay-as-you-go tax-and-transfer system with a tax on labor income and net capital income. With this restriction and the two tax rates, the paths of government debt and aggregate transfers are determined. The second policy is a savings policy for which the government does not tax the labor income of the workers. For the case in which the government debt is negative, the government has an interest-bearing deposit at the stand-in bank. Any public consumption is treated as a transfer in kind to households.

\section{Aggregates}

Output is used only for consumption by individuals and investment by the bank. Therefore, $Y_{t}=C_{t}+X_{t}$. Aggregate consumption at date $t$ is the sum of the consumption of all individuals alive at time $t$,

$$
C_{t}=\sum_{b=t-N}^{t} N^{b} c_{t}^{b},
$$

where the superscript $b$ denotes the cohort, or year of birth, and $N^{b}$ is the size of cohort $b$. Aggregate assets, $A_{t}$, are determined in the same way. In the case of aggregate hours, $H_{t}$, the summation begins at $b=t-N_{w}$.

\section{Model Parameter Values}

We consider balanced growth or steady-state equilibria. For such equilibria, $\left(Y_{t}, K_{t}, C_{t}, X_{t}, A_{t}, D_{t}\right)$ grow at rate $g,\left(Z_{t}, w_{t}, c_{t}, \psi_{t}, a_{t}\right)$ grow at rate $\gamma,\left(H_{t}, N_{t}, N^{b}\right)$ grow at rate $\eta$, and $\left(h_{t}, r_{t}, i_{t}\right)$ are constant. Along the balanced growth path, the government holds assets or issues debt in order to keep the interest rate fixed at $i$.

Before we can derive any quantitative policy implications using the model, we must calibrate the model. We calibrate this model economy to the behavior of the advanced industrialized countries. This means that the model economy mimics the behavior of these actual economies on a number of key aggregate dimensions. We need to calibrate six parameters: $(\gamma, \theta, \delta, Z, \beta, \alpha)$. The first four are technology parameters, and the last two are preference parameters. In the calibration we need values for the three demographic parameters $\left(N_{w}, N_{r}, \eta\right)$ and the two tax rates $\left(\tau_{h}, \tau_{n}\right)$. The demographic parameters and tax rates will vary across examples.

We use U.S. data to tie down the parameters. We normalize the value of aggregate output to one. We use data on the U.S. economy, where the marginal effective tax rate on labor income is $0.40 .{ }^{6}$ We set $\tau_{k}=0.20$. The tax

\footnotetext{
${ }^{6}$ See Prescott 2002.
} 
rate on corporate capital is higher than this, but the tax rates on other capital including owner-occupied housing and consumer durables are lower than this figure. We include depreciation on consumer durables in depreciation and impute services to consumer durables in much the same way that national accounts impute services to owner-occupied housing. This inclusion increases the capital cost share parameter.

The preference and technology parameters $(\gamma, \theta, \delta, \beta)$ can be calibrated using the following observations: (i) the growth rate of output is 2 percent per year; (ii) the annual capital to output ratio is 3.5; (iii) the capital cost share is 0.35 ; (iv) the depreciation of the capital stock relative to output is 0.175 ; and (v) the before-tax return on capital is 5 percent. With the tax rate on net capital income of 20 percent, the after-tax return on capital and the household interest rate are both 4 percent.

In order to calibrate the preference parameter $\alpha$ and the technology parameter $Z$, we need to use the demographic parameters, the normalization of the initial population to 100 , and the observation that the fraction of productive time of working-age people allocated to the market given the tax rate of labor of 40 percent is 0.25 . The demographic parameters are calibrated using observations from the United States. The average working life is 45 years. The average adult lifetime is 85 years. So, people are retired for 20 years. Finally, the population growth rate is 1 percent per year.

We will deal only with policies that result in the aftertax return on capital being 4 percent because this has been the after-tax return on noncorporate capital in the United States since 1929, the first year for which national income and product accounts data for the United States exist. This is the approximate return realized by households prior to 1929 on important savings instruments. For more details, see McGrattan and Prescott 2003.

The motivation for the selection of a 2 percent growth rate of output is that this has been the trend growth rate in the United States over the last 135 years. The accounts for the model economy are reported in Table 2 . The calibrated parameters are listed in Table 3. The Appendix explains the algorithm for solving for the balanced growth path of the economy.

\section{Demographic Assumptions}

The two main demographic assumptions that influence the optimal amount of government debt are the length of the retirement period and the population growth rate. Holding an individual's working life fixed, a longer re-
Table 2

Accounts with Output Normalized to 1

\begin{tabular}{lc}
\hline GNP & 1.000 \\
\hline Consumption & 0.719 \\
Investment & 0.281 \\
GNP at cost & \\
$\quad$ Depreciation & 0.175 \\
Compensation & 0.650 \\
Profits & 0.175 \\
$\quad$ Profit tax & 0.035 \\
$\quad$ After-tax profits & 0.140 \\
Aggregate inputs & \\
K & 3.500 \\
H & 18.95 \\
Individual variables & \\
Labor supply of workers & 0.25 \\
Consumption & 0.0719
\end{tabular}

tirement period increases the amount of assets a person of a given age holds. We explore various demographic assumptions. Population growth rates are now low and even negative in some advanced industrial countries. As asset positions differ with age, changing the age distribution will have consequences for the needed amount of government debt.

\section{Policy Evaluations Under Various Demographic Assumptions}

When comparing alternate retirement policies, we focus on the welfare criterion of lifetime consumption equivalents of someone entering the workforce. We emphasize that ours is a steady-state analysis. We examine the level of government debt needed for each of the retirement policies in our calibrated model.

We consider four demographic examples. First we consider an economy with 1 percent population growth, a retirement age of 65 , and a retirement period of 20 years. This first economy has roughly the same demographics as the current U.S. economy. Second, we consider an economy that might look like the future U.S. economy with no population growth, a retirement age of 65 , and a retirement period of 30 years. Third, 
Table 3

\section{Calibrated Parameter Values}

\begin{tabular}{ccl}
\hline Parameters & Values & \\
\hline$\gamma$ & 0.0200 & Average growth in per capita consumption \\
$\theta$ & 0.3500 & Capital cost share \\
$\delta$ & 0.0500 & Depreciation and capital stock \\
$Z$ & 0.0269 & Y normalized to 1 in base year \\
$\alpha$ & 0.6822 & Leisure share parameter in the utility function \\
$\beta$ & 0.9808 & Fact that consumption of each individual \\
& & grows by factor (1+ $\gamma$ ) \\
$N_{w}$ & 45 & Working lifetime \\
$N$ & 65 & Working lifetime plus retirement period \\
$\eta$ & 0.01 & Population growth rate \\
Population & 100 & \\
\hline
\end{tabular}

we look at an economy with no population growth, a retirement age of 65 , and a retirement period of 20 years. These demographics are similar to the current Japanese economy. Last, we consider an economy with no population growth, a retirement age of 60 , and a retirement period of 25 years. These demographics are similar to the current French economy.

The two main findings that emerge from the policy evaluations are that the optimal amount of government debt depends on the demographics of the economy and that the move from a tax-and-transfer retirement policy to a saving-for-retirement policy is welfare improving. A summary of the results is presented in Tables 4 and 5.

\section{Current United States}

The first case we examine roughly captures the current U.S. economy. This is the benchmark case we used for calibration. The population growth rate is 1 percent per year, and the growth rate of technology is 2 percent per year. The retirement age is 65 , and the retirement period is 20 years. The actual retirement policy in the U.S. economy is somewhere between a full tax-andtransfer system and a complete saving-for-retirement system. Here we simply compare a system with the U.S. marginal effective tax rate on labor income with a full saving-for-retirement system.
In the tax-and-transfer system, labor income is taxed at 40 percent, and net capital income is taxed at 20 percent. The equilibrium government debt to output ratio in the model economy is zero. The government capital to output ratio is 0.62 . This means the government owns 18 percent of the productive assets in the economy, which is about double the U.S. government's holdings of capital. ${ }^{7}$

If the government policy changed such that the only tax levied was on net capital income, the ratio of government debt to output would rise to 1.30 and government holding of capital would be zero. In addition, aggregate output would increase from 1.00 to 1.43 . Because of the increase in the after-tax wage faced by the worker, labor allocated to the market increases. In the tax-and-transfer system, a person entering the workforce today allocates 25 percent of his time endowment to the market. In the savings system, a worker allocates 36 percent of his time to the market. However, the reduction in leisure is more than offset by increases in consumption with the savings system. The lifetime and cross-sectional asset holdings are plotted in Figures 1 and 2.

In order to evaluate these two policies, we consider the welfare of a person entering the workforce today. By entering the economy with the savings system, his welfare is 9.2 percent higher in terms of lifetime consumption equivalents. This means that in order for him to be indifferent between the tax-and-transfer system and the saving-for-retirement system, his consumption in the tax-and-transfer economy would need to be increased by 9.2 percent in every period of his life. To summarize, the economy with the saving-for-retirement system has a significantly larger government debt to gross national product (GNP) ratio, but it provides higher welfare for an agent entering the workforce.

\section{Future United States}

Next, we examine a possible future United States economy. This economy has zero population growth, and people have a longer retirement period of 30 years. This economy has a tax-and-transfer system with a tax rate on labor income of 40 percent and net capital income of 20 percent. Aggregate output is 0.907 , and the government debt to output ratio is 1.7 . Individuals allocate 28 percent of their time endowment to the market.

\footnotetext{
${ }^{7}$ Based on information from the Bureau of Economic Analysis and the Congressional Budget Office, the U.S. government's holding of capital net of current government debt is approximately 7 percent of the aggregate U.S. capital stock.
} 
On the Needed Quantity of Government Debt

Kathryn Birkeland, Edward C. Prescott

Table 4

Policy Evaluations Under Various Demographic Assumptions

(Current and Future U.S.)

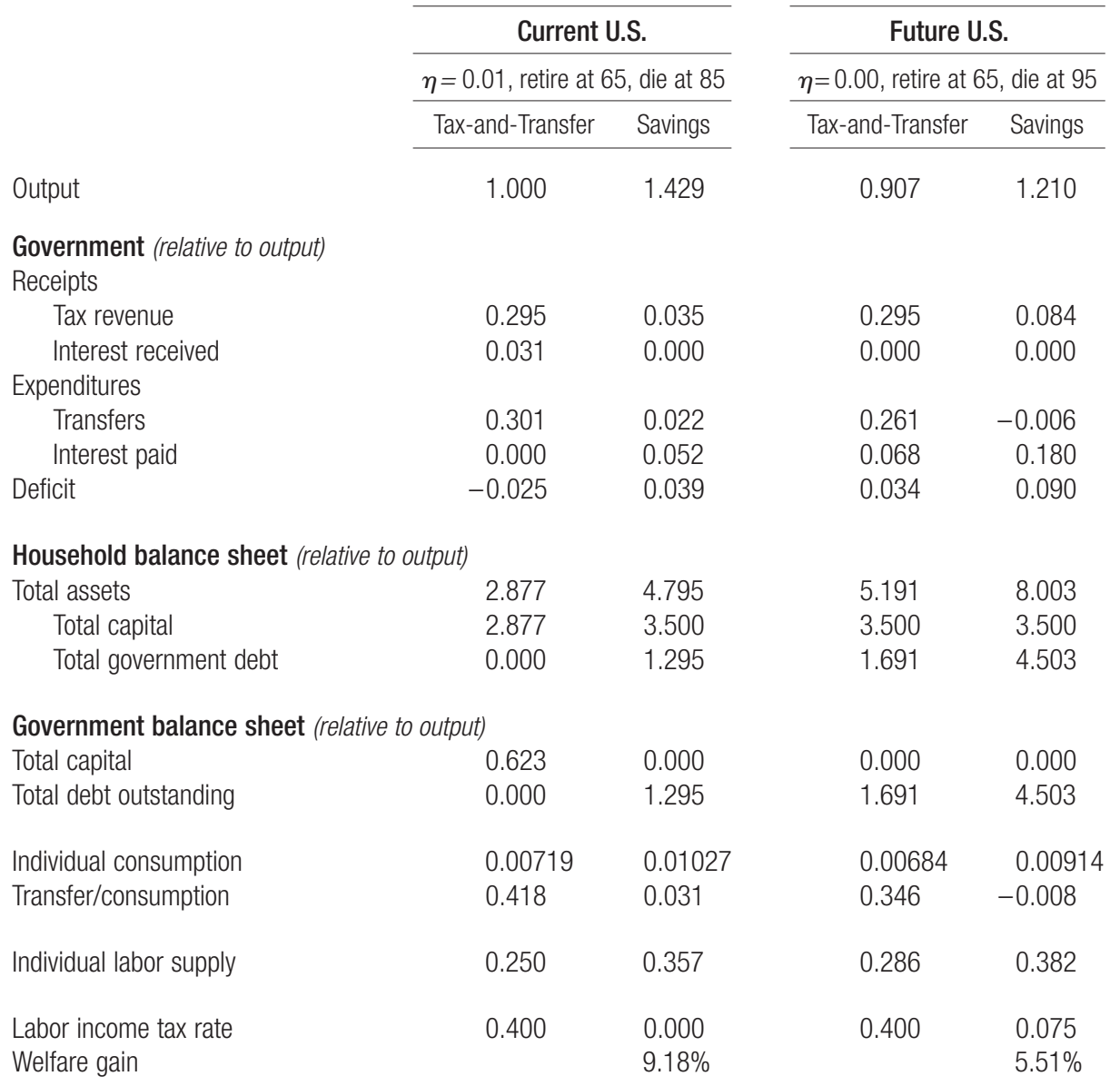

If the retirement policy changed to a saving-for-retirement system, there are no transfers from the government. The labor income tax is 7.5 percent, since tax revenues are needed to help finance the interest on the government debt. With a switch to this policy, aggregate output would increase to 1.21, and the government debt to output ratio would increase to 4.5. Individuals would now allocate 38 percent of their time endowment to the market.

Aggregate output increases but market work also increases, so what is the effect on the welfare of a person entering the workforce? In terms of lifetime consump- tion equivalents, the welfare of a person entering the workforce is 5.5 percent higher in the economy with a saving-for-retirement system than in the economy with a tax-and-transfer system.

\section{Current Japan}

The third example is motivated by the current Japanese economy. The growth rate of the population is zero. The growth rate of technology is 2 percent per year, the retirement age is 65 , and the retirement period is 20 years. The tax-and-transfer system taxes labor income 


\section{QR}

Table 5

Policy Evaluations Under Various Demographic Assumptions

(Current Japan and France)

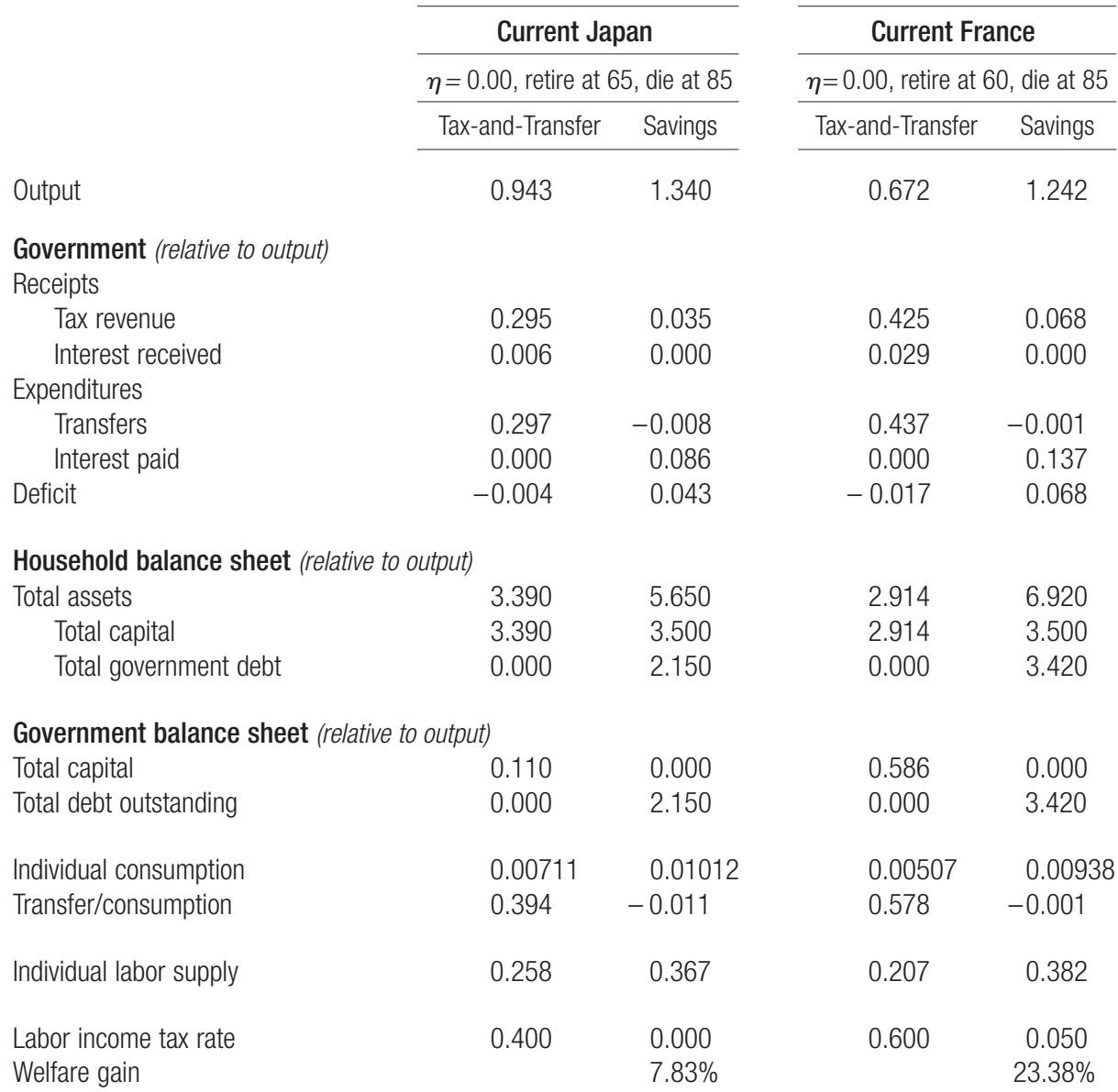

at 40 percent and net capital income at 20 percent. The government debt to output ratio is 0.0 , and the government capital to output ratio is 0.11 . The government owns 3 percent of the capital stock. Aggregate output is 0.943 , and individuals allocate 26 percent of their time endowment to the market.

In an economy with a saving-for-retirement system, there is no tax on labor income. The government debt to output ratio in this economy is 2.15 . Aggregate output increases to 1.34 , and time allocated to the market increases to 36.7 percent. In terms of lifetime consump- tion equivalents, the welfare of a person entering the workforce is 7.8 percent higher in the economy with the saving-for-retirement system than in the economy with a tax-and-transfer system. This means that a person's consumption in the tax-and-transfer economy would need to be increased by 7.8 percent in every period in order for him to be indifferent between entering the workforce in the two economies. So the move from a tax-and-transfer system to a saving-for-retirement system increases the welfare of a person entering the workforce and increases the government debt to output ratio. 
Figure 1

\section{Lifetime Asset Profile \\ for Current U.S. Demographic}

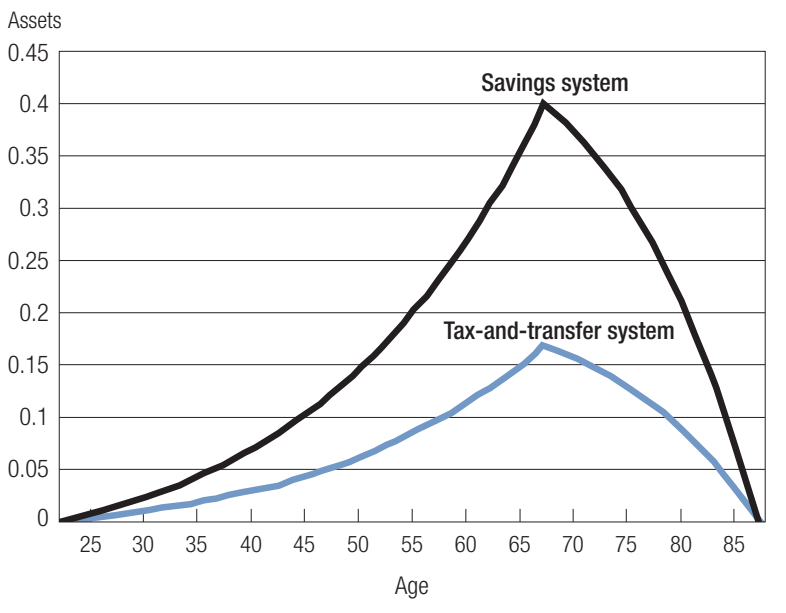

\section{Current France}

The last economy we examine is motivated by the current French economy. This economy has zero population growth, retirement at age 60 , and a retirement period of 25 years. In the tax-and-transfer system, the tax rate on labor income is 60 percent, and the tax rate on net capital income is 20 percent. Aggregate output is 0.672 , and the government has no debt. The government capital to output ratio is 0.59 , which means the government owns 11 percent of the productive assets in the economy.

With a saving-for-retirement system, the government levies a 5 percent labor income tax and a 20 percent tax on net capital income. As a result, output nearly doubles to 1.24 , and the government debt to output ratio increases to 3.42. Workers' time allocated to the market increases from 0.21 to 0.38 . This system significantly reduces the deadweight loss due to the labor income tax. As a result, the welfare gain of switching from the tax-and-transfer system to the savings system is 23 percent in terms of lifetime consumption equivalents. For economies with high labor income tax rates and long retirement periods, the switch from a tax-and-transfer system to a saving-for-retirement system generates a large welfare gain and needs a sizable amount of government debt.
Figure 2

\section{Cross-Sectional Asset Holdings for Current U.S. Demographic}

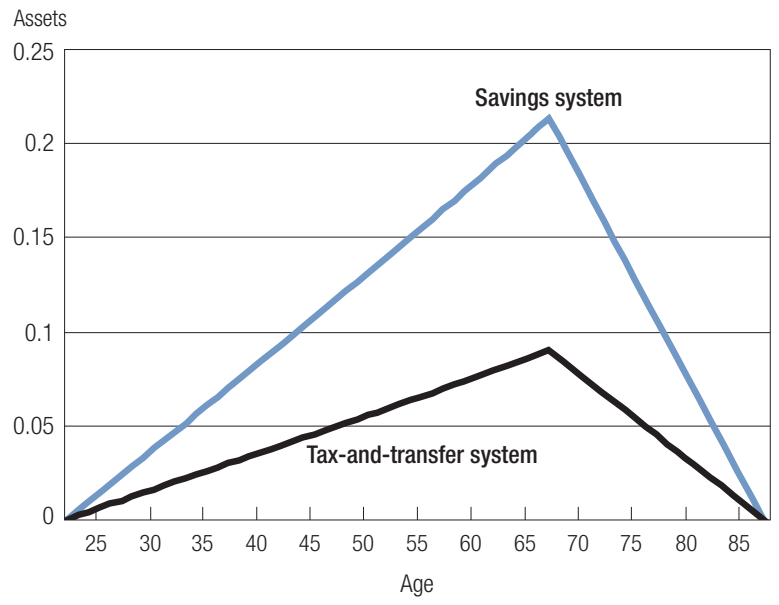

\section{Deficit Implications}

As shown in Tables 4 and 5, a saving-for-retirement system has a larger budget deficit than a tax-andtransfer system for all four examples. The large deficit means government debt increases, but it does not increase relative to output. Along the balanced growth path, the budget deficit to output ratio remains constant, as does the government debt to output ratio. In a saving-for-retirement system, the government taxes net capital income and makes interest payments and small transfers. Table 4 shows that the current U.S. savings system generates capital tax revenue equal to 3.5 percent of output. The government makes lumpsum transfers back to the people equal to 2.2 percent of output. That leaves 1.3 percent of output for paying the interest on the government debt. The total interest payments on this debt are equal to 5.2 percent of output. The deficit each period stays constant at 3.9 percent of output.

The current U.S. system is neither all tax-and-transfer nor all saving-for-retirement. There is a significant amount of private saving for retirement. The current U.S. deficit is approximately 2 percent of output. So moving to a welfare-improving saving-for-retirement system would increase the government budget deficit. 


\section{Conclusion}

With the welfare-improving saving-for-retirement system, the needed amount of explicit government debt is large if the fraction of retirees is large. With a taxand-transfer system, government debt is small, but the present value of promised transfers is large. In addition, with such a system, huge deadweight losses are incurred as a result of the high tax rate on labor income.

With the current demographics in the United States, moving from a tax-and-transfer system to a saving-forretirement system would increase the government debt to output ratio to 1.3 and would result in a welfare gain of more than 9 percent in terms of lifetime consumption equivalents. With plausible future demographics for the United States with no population growth and longer retirement periods, the government debt to output ratio would increase to 4.5 .

The gains of a switch to a saving-for-retirement system are even larger in Western Europe, where effective labor income tax rates are significantly higher than in the United States. The welfare gains are as large as 24 percent in terms of lifetime consumption equivalents. Since the needed government debt is 3.4 times gross national income (GNI), this means that the Maastricht Treaty would have to be revised to permit more than 0.6 times GNI of debt.

For all of the plausible demographic assumptions, moving from a tax-and-transfer system to a savingfor-retirement system increases government debt and is welfare improving. Government debt is not a burden on our grandchildren. Our grandchildren will be better off in a world with a saving-for-retirement system and sizable government debt.

\section{Appendix}

The following specifies the algorithm used to find the equilibrium of the model described in the subsection entitled "The Pure Consumption Loan Model." We are looking for an equilibrium where $\left(Y_{t}, K_{t}, C_{t}, X_{t}, A_{t}, D_{t}\right)$ grow at rate $g$, $\left(Z_{t}, w_{t}, c_{t}, \psi_{t}, a_{t}\right)$ grow at rate $\gamma,\left(H_{t}, N_{t}, N^{b}\right)$ grow at rate $\eta$, and $\left(h_{t}, r_{t}, i_{t}\right)$ are constant. Along the balanced growth path, the government holds assets or issues debt in order to keep the interest rate fixed at $i$. Given the parametric set of economies, we are looking for a balanced growth path of this economy given the interest rate, the tax rate on net capital income, and the labor income tax rate.

The first step is to solve for the rental price of capital, $r$, using the capital tax rate and the depreciation rate along with the bank's no profit condition, $i=\left(1-\tau_{k}\right)(r-\delta)$. The second step is to solve for the capital-labor ratio using the profit-maximizing condition of the stand-in firm with respect to capital, $r=\theta(Y / K)$. Then solve for the capital-labor ratio using the production function, $(Y / K)=Z(H / K)^{1-\theta}$. Next, solve for the real wage, $w$, using the stand-in firm's other profit-maximizing condition, $w=(1-\theta) Z(K / H)^{\theta}$. The next step is to solve for per capita consumption, $c$, individual labor supplied, $h$, aggregate consumption, and aggregate labor supply. This step requires solving four equations in four unknowns. Given the interest rate and the calibrated values for $\beta$ and $\gamma$, the intertemporal growth rate of consumption for an individual is equal to the growth rate of per capita consumption across cohorts. This means that even though the consumption of 25year-olds today is higher than that of 25 -year-olds yesterday, the consumption this period is the same for all individuals.

$$
\begin{array}{ll}
c_{2}^{1}=\beta(1+i) c_{1}^{1}: \begin{array}{l}
\text { intertemporal condition for } \\
\text { the household }
\end{array} \\
c_{2}^{2}=(1+\gamma) c_{1}^{1} \quad \begin{array}{l}
: \text { growth rate of per capita } \\
\text { consumption across cohorts }
\end{array}
\end{array}
$$

So when $\beta(1+i)=(1+\gamma)$, the consumption of each cohort is the same in period $t, c_{2}^{2}=c_{2}^{1}=c$. The four equations in four unknowns are

$$
\begin{array}{ll}
C=\sum_{i=-N}^{1}(1+\eta)^{i} N^{1} c & \begin{array}{l}
: \text { the definition of } \\
\text { aggregate consumption }
\end{array} \\
H=\sum_{i=-N w}^{1}(1+\eta)^{i} N^{1} h & \begin{array}{l}
: \text { the definition of } \\
\text { aggregate labor supply }
\end{array} \\
C+(\gamma+\delta) K=Z K^{\theta} H^{1-\theta} & : \begin{array}{l}
\text { the aggregate } \\
\text { resource constraint }
\end{array}
\end{array}
$$


On the Needed Quantity of Government Debt

Kathryn Birkeland, Edward C. Prescott

\section{References}

$$
\frac{\alpha c}{(1-h)}=\left(1-\tau_{h}\right) w
$$

\section{: the household's \\ intratemporal \\ marginal condition,}

where $N^{1}$ is the size of cohort 1 .

After solving for $c$ and $h$, solve for $\psi$ using the lifetime budget constraint of the household:

$$
\begin{aligned}
& \sum_{t=1}^{N} \frac{\left(c_{t}-\psi_{t}\right)}{(1+i)^{t-1}}-\sum_{t=1}^{N_{w}} \frac{\left(1-\tau_{h}\right) w_{t} h_{t}}{(1+i)^{t-1}}=0 \\
& \sum_{t=1}^{N_{W}} \frac{1}{(1+i)^{t}}\left(c_{t}-\left(1-\tau_{h}\right) w_{t} h_{t}\right)-\sum_{t=N}^{N} \frac{\psi_{t}}{(1+i)^{t}}=0
\end{aligned}
$$

The next step is to solve for aggregate assets in the economy in period $t=1, A_{1}=\sum_{b=1-N}^{1} a_{1}^{b}$.

First, calculate the lifetime asset profile of an individual born in period $1 \mathrm{using} a_{t+1}=a_{t}\left(1+i_{t-1}\right)+\left(1-\tau_{h}\right) w_{t} h_{t}+\psi_{t}-c_{t}$ and $a_{1}^{1}=0$.

Since the economy is on the balanced growth path and we know the vector of $\left\{a_{t}^{1}\right\}_{t=1}^{N}$, we can solve for the vector of $\left\{a_{1}^{b}\right\}_{b=-N}^{1}$ using the following relationship: $a_{t}^{-b}=a_{b}^{t} /(1+\gamma)^{b}$.

Therefore, the total assets in the economy in period 1:

$$
\begin{aligned}
& A_{1}=\sum_{j=1}^{N} \frac{a_{j}^{1} N^{1}}{(1+\eta)^{j-1}(1+\gamma)^{j-1}} \\
& A_{1}=\sum_{j=1}^{N} \frac{a_{j}^{1}}{(1+\eta)^{j}(1+\gamma)^{j}} N^{1} .
\end{aligned}
$$

The final step solves for government debt, $D$. First, using the bank's balance sheet condition, $A=K+D$ and aggregate assets, find $D$. A corresponding step involves looking at the government's budget constraint. Solve for total tax revenue and total transfers as follows:

$$
\begin{aligned}
& \text { Revenue }=\tau_{k}(r-\delta) K+\tau_{h} w H . \\
& \text { Transfers, } \Psi=\sum_{i=1-N}^{1}(1+\eta)^{i} N^{1} \psi
\end{aligned}
$$

Then find government debt using the government's budget constraint:

$$
\text { Revenue }=\Psi+(i-\gamma) D
$$

Abel, Andrew B., N. Gregory Mankiw, Lawrence H. Summers, and Richard J. Zeckhauser. 1989. Assessing dynamic efficiency: Theory and evidence. Review of Economic Studies 56 (January): 1-19.

Diamond, Peter A. 1965. Technical change and the measurement of capital and output. Review of Economic Studies 32 (October): 289-98.

Hansen, Gary D. 1985. Indivisible labor and the business cycle. Journal of Monetary Economics 16 (November): 309-27.

Lucas, Robert E., Jr., and Leonard A. Rapping. 1969. Real wages, employment, and inflation. Journal of Political Economy 77 (September/October): 721-54.

McGrattan, Ellen R., and Edward C. Prescott. 2003. Average debt and equity returns: Puzzling? American Economic Review 93 (May): 392-97.

Prescott, Edward C. 2002. Richard T. Ely lecture: Prosperity and depression. American Economic Review 92 (May): 1-15.

.2006. Nobel lecture: The transformation of macroeconomic policy and research. Journal of Political Economy 114 (April): 203-35.

Prescott, Edward C., and José-Víctor Ríos-Rull. 2005. On equilibrium for overlapping generations organizations. International Economic Review 46 (November): 1065-80.

Prescott, Edward C., Richard Rogerson, and Johanna Wallenius. 2007. Lifetime aggregate labor supply with endogenous workweek length. Working paper. Arizona State University.

Rogerson, Richard. 1988. Indivisible labor, lotteries, and equilibrium. Journal of Monetary Economics 21 (January): 3-16.

Rogerson, Richard, and Johanna Wallenius. 2007. Micro and macro elasticities in a life cycle model with taxes. Working paper. Arizona State University.

Samuelson, Paul. 1958. An exact consumption-loan model of interest with or without the social contrivance of money. Journal of Political Economy 66 (December): 467-82. 